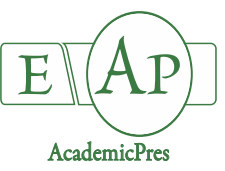

Ortega-García J et al. (2021)

Notulae Botanicae Horti Agrobotanici Cluj-Napoca

Volume 49, Issue 3, Article number 12414

DOI: $10.15835 /$ nbha 49312414

Research Article

\title{
Bacillus amyloliquefaciens as a halo-PGPB and chitosan effects in nutritional value and yield production of Asparagus officinalis $\mathrm{L}$. under Sonora desert conditions
}

\author{
Jesús ORTEGA-GARCÍA ${ }^{1}$, Ramón J. HOLGUÍN-PEÑA², \\ Pablo PRECIADO-RANGEL ${ }^{3}$, Reyna R. GUILLÉN-ENRÍQUEZ ${ }^{3}$, \\ Gerardo ZAPATA-SIFUENTES ${ }^{3}$, Juan M. NAVA-SANTOS 4 , \\ Edgar O. RUEDA-PUENTE ${ }^{5 *}$
}

\author{
${ }^{1}$ Universidad de Sonora, Departamento de Ciencias Químico Biológicas y Agropecuarias de la Unidad Regional Norte, \\ Mexico; jesus.ortega@unison.mx \\ ${ }^{2}$ Centro de Investigaciones Biológicas del Noroeste, Programa de Agricultura en Zonas Áridas, Av. Instituto Politécnico Nacional 195 \\ Col. Playa Palo de Santa Rita Sur, C.P. 23096, La Paz, Baja California Sur, México; jholguin04@cibnor.mx \\ ${ }^{3}$ Instituto Tecnológico Nacional de México - Instituto Tecnológico de Torreón, Torreón, Coahuila, México; \\ ppreciador@yahoo.com.mxirreguillen@outlook.com;gdo.zapata81@gmail.com \\ ${ }^{4}$ Universidad Autónoma Agraria Antonio Narro. Unidad Laguna, Carretera periférico s/n. Colonia Valle Verde. CP: 27054 Torreón, \\ Coahuila, México; juan.manuelnava@hotmail.com \\ ${ }^{5}$ Universidad de Sonora, Departamento de Agricultura y Ganadería, Boulevard Luis Encinas y Rosales s/n. Col. Centro, C.P. 83000, \\ Hermosillo, Sonora, México; erueda04@santana.uson.mx (*corresponding author)
}

\begin{abstract}
Asparagus officinalis L. is a crop associated with arid and dry environments of arid deserts; its tender product is considered a gourmet food for its exclusive consumption and its high prices. Among the main attributes of this vegetable are being a product low in calories, fat and cholesterol, with a high content of vitamin $\mathrm{C}$, as well as rich in potassium and calcium phosphate. The indiscriminate use of synthetic fertilizers in agricultural crop production systems, as well as the increasing dependence, they cause deterioration of the physical and chemical properties of the soil, in addition have a variable impact on the composition and functions of the soil microbiota. Under indigenous area "Seris" in Sonora desert conditions (salinity and high ${ }^{\circ} \mathrm{C}$ ), var. 'Early California' of asparagus was biofertilized with Bacillus amyloliquefaciens (Ba) as a halo-PGPB and chitosan (QUI) to evaluate nutritional value and yield-production. Results showed that Ba and QUI in the vegetative period increased the emergence rate $(\geq 15 \%)$, nitrates in sap $(\geq 10 \%)$, fresh and root weight and crown $(\geq 25 \%)$; significant values in its subsequent production stage of shoots for human consumption (proximal values such as protein ( $\geq 33 \%)$, and carbohydrates $(\geq 20 \%)$, in addition to $\mathrm{K}^{+}(\geq 9 \%)$ and Vit C $(\geq 15 \%)$ compared with the control, were obtained. These results express the possibility of using Bacillus amyloliquefaciens as a halo-PGPB and chitosan as a biofertilizer of marine origin in asparagus under Sonora desert conditions.
\end{abstract}

Keywords: biofertilizer; halotolerant crop; mitigation; promoter effect; saline intrusion

Received: 27 Jul 2021. Received in revised form: 13 Aug 2021. Accepted: 22 Aug 2021. Published online: 03 Sep 2021.

From Volume 49, Issue 1, 2021, Notulae Botanicae Horti Agrobotanici Cluj-Napoca journal uses article numbers in place of the traditional method of continuous pagination through the volume. The journal will continue to appear quarterly, as before, with four annual numbers. 


\section{Introduction}

Interest in Asparagus officinalis L. based on its nutritional value, its characteristic flavor and the presence of biotic compounds has been increasing lately. In 2006 it was estimated that there were 210,000 ha planted with this crop worldwide (Khate et al., 2019; Djalali et al., 2020). China ranks first in productivity with approximately $84 \%$ of world production, which is mostly dedicated to domestic consumption. It is also widely cultivated in Spain (30\%), Germany (18\%), France (15\%), Italy (15\%) and Greece (14\%) (Waskiewicz et al., 2013). In Latin America, Peru Country is an important producer which has the climatic conditions that allow it to produce throughout the year and produces $4 \%$ of world production. However, In Mexico, the cultivation of asparagus constitutes a source of work and income from the exports of the product and given its proximity to the United States; Mexico is the main exporter of fresh asparagus to this country, equivalent to $51 \%$ of total imports, surpassing Peru, which, in 2010, was the main exporter to the United States (Quilamba et al., 2004). In 2019, 4,654 million pesos were generated by producing 186,420 tons from 47,828 ha harvested in Mexico. The main asparagus producing states in Mexico are: Sonora, Baja California, Guanajuato, Baja California Sur and Queretaro, where the $98.9 \%$ of the supply is concentrated in these states, which is equivalent to approximately 256,225 tons. Sonora is the most important asparagus producing state at the national level, contributing $69.4 \%$ of the production value and contributing a volume of 149,808 tons. The commercial value of the asparagus crop is estimated at 6,485 million pesos, which is equivalent to 24,000 ha. planted (SAGARPA, 2017). Caborca is the main asparagus producing region in the State of Sonora, it has more than 15,000 ha planted and it is the most important for exports to the United States. Asparagus production in this region generates numerous jobs each year, around 2,000 employees in the largest companies only during the harvest period. From 2013 to 2018, asparagus production grew from 125,000 to 208,435 tons, which represents an increase in real terms of $66.5 \%$ at the national level. Mexico's exports to the United States at the end of 2018 reached 147.9 million dollars, equivalent to 106,432 tons of asparagus. In Sonora state, there are 13 native people called "indigenous town's"; one of them are the "Comcaac" or "Seris" which it means (sand walkers). Seris, an Amerindian town that lives in the Northwest of the Sonora, its number of inhabitants no more than 5,000 people; they have their own uses, customs, traditions and language; they have their own traditional authorities, who are elected by vote, and their hierarchy is respected along with Mexican civil laws. Seris territory is approximately of $1,500 \mathrm{~km} 2$, considering the Tiburon Island, which it is sited in the Gulf of California and the largest in Mexico country. Due the Seri town are living close to coastline, has a particular and economical activities considering halophytes (salt tolerant plants) with agro-industrial importance (Salicornia bigelovii and Oreganum vulgare "native" from coastline and asparagus) and aquaculture mainly shrimp farming. In recent years, with asparagus to obtain high productions, they are using high amounts of chemical fertilizers $\left(600-1,300 \mathrm{~kg} / \mathrm{ha}\right.$ ) and due the increases in ambient temperature (till to $52^{\circ} \mathrm{C}$ ), researchers are detecting in soil "Seri" a phenomenon named "saline intrusion" (Beltrán et al., 2017). Moreover, unselective use of these nourishments forces the increasing salinity and severely injuries soil microorganism's structure and configuration (Jefferies, 1977; Kapulnik et al., 1981; Nahid and Gomah, 1991). Based on the federal support from the nation and in order to produce subproducts based on last crops (bread, tortilla, etc.), they are demanding a system production with asparagus which it will be proposed with the use of biofertilizers like a plant growth promoting bacteria. Moreover, because Seri town is a strong producer of farmed shrimp, they propose the application of bio derivatives from crustacean exoskeletons such as chitosan (QUI).

The role of plant growth-promoting halo-bacteria (Halo-PGPB) is widely recognized (Efe, 2020). Various studies confirm that: a) do not require the internal invasion of tissues in plants, as occurs in fungi microrrhizal with the formation of nodules or arbuscules in the case of Rhizobium; b) they have a high population density in the rhizosphere after inoculation, since a rapidly declining population has low competitive capacity with the native soil microflora; $c$ ) that they present effective colonization capacity on the root surface reverberating they can positively influence the growth of the plant and d) that they do not cause harm to man or other microorganisms; also Halo-PGPB have the ability to associate with the root system, 
benefit the plant and mitigate the effect of salinity in the soil; they improve crop yields by providing them with nutrients through atmospheric nitrogen fixation, phosphate solubilization, and also influence the plant due to its production of phytohormones, such as auxins and ghibellins (AG3) (Efe, 2020).

Chitosan for its part is an abundant component in organisms of marine origin such as crustaceans; it is a very abundant compound in nature and very friendly to the environment, thanks to characteristics such as its amino group, it has been widely used in different areas, since it is biocompatible with many biological systems. In the area of agriculture, chitosan has improved the germination process, harvest yields and adsorption of micronutrients from different crops; in addition chitosan stimulates the defense mechanism of plants and the formation of physical barriers; also it has been mentioned that chitosan when applied in the initial flowering stage in crops, stimulates growth in stems, leaves and fruit size, increasing yields (Hadwiger et al., 1984; Guan et al., 2009; Peña-Datoli et al., 2016; López-Corona 2019a,b).

Till to date, studies on the interaction of asparagus with plant growth promoting bacteria (PGPB) and chitosan of marine origin and are null; for this reason this study was carried out to know the effect of Bacillus amyloliquefaciens as a PGPB vs chitosan and their mixture to increase the knowledge about in nutritional value and asparagus yield in the indigenous area "Seris" under Sonora desert conditions, thereby contributing to the use of PGPB and by-products of marine origin which in most cases contribute to polluting the environment.

\section{Materials and Methods}

\section{Studyarea}

The research was developed in an agricultural area of the Comcaac community located at the coordinates: $29^{\circ} 00^{\prime} 59.5^{\prime \prime N}$ North Latitude and $112^{\circ} 09^{\prime} 43.5^{\prime \prime} \mathrm{W}$ (Figure 1), located at a height of $35 \mathrm{~cm}$ above sea level and 131 kilometers to the west of the city of Hermosillo, Sonora, Mexico. Considering the Köppen climatic classification criteria, modified by García (1981), the area where the study was carried out has a precipitation no greater than $150 \mathrm{~mm}$ and a temperature variation; in the months of May to August a temperature that ranges from 36 to $48{ }^{\circ} \mathrm{C}$ and in the months of September to February between 24 to $38^{\circ} \mathrm{C}$. It rains mainly between July and September, mostly in the form of showers with strong gusts of wind. Winter (between December and February) is pleasant, with cool nights and warm days, no frost or snow.

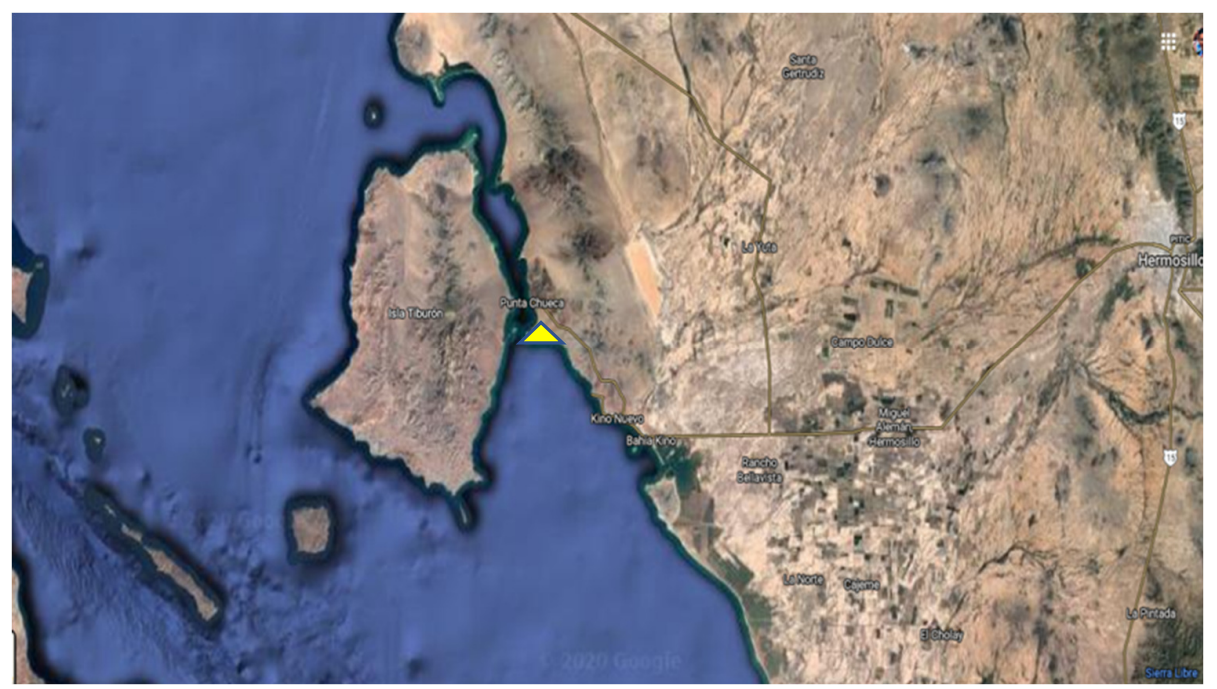

Figure 1. Location of the study area on the effect of halo-Bacillus amyloliquefaciens as a PGPB and chitosan on asparagus yield in the indigenous area "Seris" under Sonora desert conditions 


\section{Preparation of the chitosan bio-product of marine origin}

Shrimp exoskeletons obtained from fishing by Seris fishermen-anglers were used; subsequently exoskeletons were crushed to a particle size of less than $250 \mu \mathrm{m}$ using a sieve. The chitosan was obtained in different stages: first, the chitin was extracted and later the chitosan was obtained. The chemical method proposed by Hernández Cocoletzi et al. (2009) was used, where solutions of $0.6 \mathrm{~N} \mathrm{HCl}$ and $1 \%$ and $50 \%$ $\mathrm{NaOH}$ were used, in order to remove lipids, minerals, pigments and proteins bound to chitin; for this, a demineralization of the exoskeletons was carried out, using $0.6 \mathrm{~N} \mathrm{HCl}$ in a $1: 11$ solid-liquid ratio at a temperature of $30{ }^{\circ} \mathrm{C}$ for 3 hours. The sample was then deproteinized with a $1 \% \mathrm{NaOH}$ solution at a temperature of $28^{\circ} \mathrm{C}$ for 24 hours of constant stirring to ensure complete deproteinization. When chitin was obtained, deacetylation was carried out using $50 \% \mathrm{NaOH}$ in a $1: 4$ solid-liquid ratio, under the following conditions: first for 2 hours at $60^{\circ} \mathrm{C}$ and then for 2 hours at $100{ }^{\circ} \mathrm{C}$. Finally, the final product obtained was chitosan with a degree of deacetylation of $65 \%$. It should be noted that in each step of the process indicated, the product obtained was subtly washed with distilled water until a neutral $\mathrm{pH}$ was obtained. For the overall performance of the chitosan extraction process in the exoskeletons, the following expression was used: $R G=$ RR / RT X 100 (Equation 1); where: RT: theoretical yield, quantity in grams of the sample with which the process was started; RR: actual yield, quantity in grams of the final product (chitosan). The chitosan concentrations used in the treatments were 50 and $100 \%$.

Inoculation with Bacillus amyloliquefaciens $(\mathrm{Ba})$ and Quitosano (QUI) in seed of asparagus var. 'Early California'.

Bacillus amyloliquefaciens (Ba) a halobacteria was obtained by Renganathan et al. (2018), it is classified in GenBank under accession number KM652480. Ba was developed in liquid medium OAB with $0.5 \mathrm{M} \mathrm{NaCl}$. Incubation conditions was continuously stirred $(120 \mathrm{rpm})$ and at a temperature of $30^{\circ} \mathrm{C}$ (Reinhold et al., 1987). Between 14 and $16 \mathrm{~h}$ (logarithmic phase) elapsed, the concentration of the culture was determined, according to the following procedure: $1 \mathrm{~mL}$ of the culture $\mathrm{Ba}$, was poured into a cell for spectrophotometer (master spectrum FISHER SCIENTIFIC 415), taking the reading of absorbance at a wavelength of $540 \mathrm{~nm}$ against a liquid $\mathrm{OAB}$ medium control with $0.5 \mathrm{M} \mathrm{NaCl}$ without bacteria. The bacterial suspension was diluted to an absorbance of 1.00 unit, then was prepared concentration of $\mathrm{Ba}$ at $1 \times 10^{8}$ and $1 \times 10^{10} \mathrm{CFU} / \mathrm{mL}$ for the respective treatments (Table 1). $10 \mathrm{~g}$ of asparagus seed ( 48 seeds $\pm 3 / \mathrm{gr}$ ) were added to the bacterial culture and in a $50 \mathrm{~mL}$ Kitazato flask, they were subjected to vacuum at $600 \mathrm{~mm} \mathrm{Hg}$ for $5 \mathrm{~m}$ (Carrillo et al., 1988). According to quitosano (QUI), seeds of asparagus was submerged in each treatment based on chitosan of two concentrations ( 50 or $100 \%)$ with $\mathrm{Ba}\left(1 \times 10^{8}\right.$ or $\left.1 \times 10^{10} \mathrm{CFU} / \mathrm{mL}\right)$ for $15 \mathrm{~min}$ (Table 1$)$. Previously the inoculation of seeds of asparagus, the logarithmic phase of $\mathrm{Ba}$ was verified to detect if QUI affected the viability of $\mathrm{Ba}$, obtaining null results in viability. This test was realized by triplicate.

Basins of $7 \mathrm{~m}$ long and $1.5 \mathrm{~m}$ wide were used; the seed inoculated and treated according to Table 1 , were sowed a $3 \mathrm{~cm}$ deep and $3 \mathrm{~cm}$ of distance between seeds $\left(33 \mathrm{seeds} / \mathrm{m}^{-1}\right)$; the sowed was with double row, with a distance between rows of $40 \mathrm{~cm}$; in this basin $460 \pm 6$ experimental units (seeds) by treatment in $7 \mathrm{~m}$. Before sowed, an analysis was carried out on the soil-substrate to determine the content of organic matter (OM), macro- and micronutrients, as well as the $\mathrm{pH}$ of the soil (Table 2). 
Table 1. Experimental treatments corresponding to var Early California of asparagus inoculated with haloBacillus amyloliquefaciens (Ba) as a PGPB and chitosan (QUI) in the indigenous area "Seris" under Sonora desert conditions

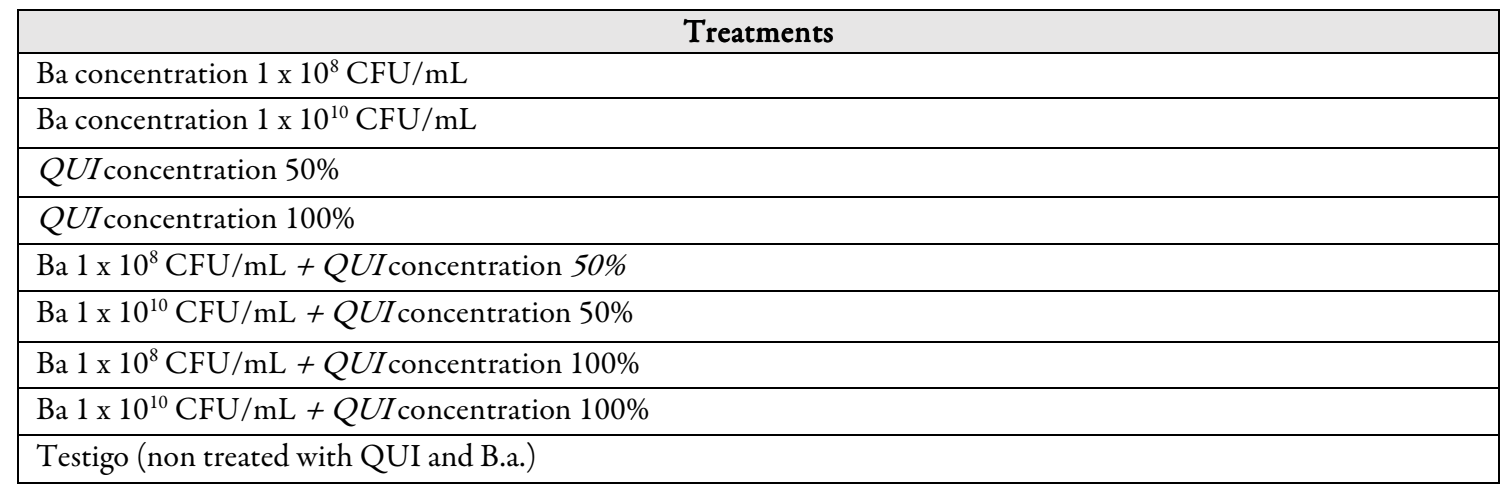

Table 2. Physical and chemical parameters of the substrate in the experimental basins under conditions of the Altar desert, Sonora

\begin{tabular}{|l|l|l|c|c|c|c|c|c|c|c|}
\hline Texture & $\mathrm{pH}$ & $\begin{array}{c}\mathrm{CE} \\
\mathrm{dS} / \mathrm{m}^{-1}\end{array}$ & $\begin{array}{c}\mathrm{M} . \mathrm{O} . \\
\%\end{array}$ & $\mathrm{RAS}$ & $\begin{array}{c}\mathrm{NO}_{3} \\
\mathrm{mg} / \mathrm{kg}^{-1}\end{array}$ & $\begin{array}{c}\mathrm{NO}_{2} \\
\mathrm{mg} / \mathrm{kg}^{-1}\end{array}$ & $\begin{array}{c}\mathrm{Ca} \\
\mathrm{mg} / \mathrm{kg}^{-1}\end{array}$ & $\begin{array}{c}\mathrm{Mg} \\
\mathrm{mg} / \mathrm{kg}^{-1}\end{array}$ & $\begin{array}{c}\mathrm{K} \\
\mathrm{g} / \mathrm{L}^{-1}\end{array}$ & $\begin{array}{c}\mathrm{Na} \\
\mathrm{g} / \mathrm{L}^{-1}\end{array}$ \\
\hline Sand/loam & $\begin{array}{l}\mathbf{1 0 .} \\
.04\end{array}$ & $\begin{array}{l}11 . \\
2.5\end{array}$ & 0.02 & 8.82 & 0.09 & 0.01 & 5.80 & 19.36 & 0.1 & 1.6 \\
\hline
\end{tabular}

\section{Edafoclimatic conditions}

The conditions $\left(\mathrm{T}{ }^{\circ} \mathrm{C}\right.$, H.r., photsynthetically active radiation (Rfa: $\left.\mathrm{me} / \mathrm{M}^{-2} \mathrm{~s}^{-1}\right)$ ) and annual mean insolation $(\mathrm{Ima} / \mathrm{h})$, on the field conditions are indicated in Table 3 . As a first phase in sowing and rooting, and emergency, and production stage of the edible plant, during 30 days after sowing (days), daily watering of six hours were developed ( $2 \mathrm{~h}$ from 7 to $9 \mathrm{am} ; 12$ at $2 \mathrm{pm}$ and 6 to $8 \mathrm{pm}$ ).

The characteristics of the tape irrigation was $21 / \mathrm{h}$, caliber 16 with $40 \mathrm{~cm}$ of distance between dropper and dropper (Brand Rivulis). As a second phase, the irrigation was with $2 \mathrm{~h} /$ day irrigation in cutting green foliage stage; in burning foliage stage was stopped the watering. In harvest of shoots stage, the irrigation was with 4 h day irrigation. After the end of the harvest (March), a heavy irrigation was carried out during one week for 24 hours, originating $58 \mathrm{~h}$ irrigation per week; later in the $2 \mathrm{nd}$ week from the harvest (March) it was reduced to $18 \mathrm{~h}$ irrigation per week; then by 16 and then $14 \mathrm{~h}$ irrigation per week. It should be noted that when the temperature increases $\left(<44^{\circ} \mathrm{C}\right)$ the watering's rise was to $40 \mathrm{~h}$ irrigation per week until the cutting of foliage for its respective burning, and wait immediately the promotion of shoots. Quality of the water used in the irrigation of Asparagus (var. Early California) production also was analyzed, to evaluate the effect of haloBacillus amyloliquefaciens $(\mathrm{Ba})$ as a PGPB and chitosan (QUI) in the indigenous area "Seris" under Sonora desert conditions (Table 4) 
Table 3. Environmental conditions $\left(\mathrm{T}^{\circ} \mathrm{C}, \mathrm{Hr}\right.$, photosynthetically active radiation ( $\mathrm{Rfa}: \mathrm{me} / \mathrm{M}^{-2} \mathrm{~s}^{-1}$ ) and average annual insolation (Ima h.day), present in the different phenological stages of asparagus production (var Early California) treated (program of innoculation) by the effect of halo-Bacillus amyloliquefaciens (Ba) as a PGPB and chitosan (QUI) in the indigenous area "Seris" under Sonora desert conditions

\begin{tabular}{|c|c|c|c|c|c|}
\hline Stage phenologic/ $1^{\text {st }}$ study & $\begin{array}{c}\mathrm{T} \\
\left({ }^{\circ} \mathrm{C}\right)\end{array}$ & $\begin{array}{l}\text { H.r. } \\
(\%)\end{array}$ & $\begin{array}{c}\mathrm{Rfa} \\
\left(\mathrm{me} / \mathrm{m}^{-2} \mathrm{~s}^{-1}\right)\end{array}$ & Imahr & $\begin{array}{l}\text { Innoculation } \\
\text { program (das) }\end{array}$ \\
\hline Sowed and rooting $(15 \mathrm{Oct} / 2018)$ & $39 \pm 2{ }^{\circ} \mathrm{C}$ & $<45 \% \mathrm{HR}$ & 510.33 & 8 & $\begin{array}{l}\text { In sowed and } \\
\text { before } 34 \text { das }\end{array}$ \\
\hline $\begin{array}{l}\text { Emergency and production stage of the } \\
\text { edible plant (Nov/2018-feb/2019) }\end{array}$ & $36 \pm 4^{\circ} \mathrm{C}$ & $<35 \% \mathrm{HR}$ & 485.22 & 7 & 80 and 120 \\
\hline $\begin{array}{l}\text { Development of lateral branches (March- } \\
\text { july/2019) }\end{array}$ & $45 \pm 3{ }^{\circ} \mathrm{C}$ & $<15 \% \mathrm{HR}$ & 580.32 & 10 & 150 and 180 \\
\hline $\begin{array}{l}\text { Side branch growth (July-Nov/2019) } \\
\text { Cutting green foliage and burning foliage } \\
\text { (Dec-2019) }\end{array}$ & $\begin{array}{l}46 \pm 4^{\circ} \mathrm{C} \\
36 \pm 4^{\circ} \mathrm{C}\end{array}$ & $\begin{array}{l}<10 \% \mathrm{HR} \\
<35 \% \mathrm{HR}\end{array}$ & $\begin{array}{l}589.43 \\
495.22\end{array}$ & $\begin{array}{c}11 \\
8\end{array}$ & $\begin{array}{c}250,300,365 \\
\text { NA }\end{array}$ \\
\hline $\begin{array}{l}\text { Harvest of shoots to consume (January- } \\
\text { March-2020) }\end{array}$ & $38 \pm 3^{\circ} \mathrm{C}$ & $<15 \% \mathrm{HR}$ & 560.12 & 0 & $450,480,540$ \\
\hline
\end{tabular}

Rfa: photosynthetically active radiation; Ima: Average annual sunshineday; NA: no application; das: days after sowing

Table 4. Quality of the water used in the irrigation of Asparagus (var. Early California) production, in the effect of halo-Bacillus amyloliquefaciens (Ba) as a PGPB and chitosan (QUI) in the indigenous area "Seris" under Sonora desert conditions

\begin{tabular}{|l|c|c|c|c|c|}
\hline \multicolumn{1}{|c|}{ Type of water } & $\mathrm{pH}$ & $\begin{array}{c}\text { Salinity } \\
\mathrm{ppm}\end{array}$ & $\begin{array}{c}\text { C.E. } \\
\mathrm{wdS} / \mathrm{m}\end{array}$ & $\begin{array}{c}\text { Nitrites } \\
\left(\mathrm{NO}_{2}\right) \mu \mathrm{m} / \mathrm{L}\end{array}$ & $\begin{array}{c}\text { Nitrates } \\
\left(\mathrm{NO}_{3}\right) \mu \mathrm{m} / \mathrm{L}\end{array}$ \\
\hline Brackish water & 8.0 & 6,500 & 8.17 & $0.318-0.321$ & $6.01-6.28$ \\
\hline
\end{tabular}

Laboratory Biogeochemical water.

This irrigation system has been previously developed in the asparagus production systems in the Caborca region. The experience generated in the period of economic useful life of the crop -10 or 12 years-, has been extended in different regions of the Mexico country, considering the present evapotranspiration of each region. In the Seri community, is no exception. Fit in mention that our study was carried out and evaluated till to harvest of shoots stage.

\section{Biofertilization program on the root crown}

The biofertilization program by inoculation in liquid form was depositing with the help of a pizeta, 10 $\mathrm{mL}$ of CFU/mL or $10 \mathrm{~mL}$ of QUI on each root crown according to the treatments to be studied. Table 3 shows the program schedule.

\section{Variables evaluated}

The emergence rate and the percentage were measured and recorded once the seedlings emerged from the substrate $=$ plants $\mathrm{m}^{-1}=($ four days after sowing $=$ days $)$. The number of emergencies edible plants was recorded by readings (evaluations) every third day (Emergence Rate), and finally the percentage of emergency (\%) was measured after the 20th day of trial. Using the next formula, the emergency rate was calculated (Maguire, 1962): $\mathrm{M}=\mathrm{n} 1 / \mathrm{t} 1+\mathrm{n} 2 / \mathrm{t} 2+\ldots \mathrm{n} 25 / \mathrm{t} 20$, where $\mathrm{n} 1, \mathrm{n} 2, \ldots \mathrm{n} 20$ are the numbers of emerged of plants at times $\mathrm{t} 1, \mathrm{t} 2, \ldots \mathrm{t} 20$ in days. The data of emergency percentage were analyzed taking into account a transformation to the arc-sin (Sokal and Rohfl, 1988). The emergence rate, which it is the sum of counted emergency seedling per day, was evaluated counting plants $\mathrm{m}^{-1}$. This variable also was evaluated in harvest of shoots to consume (January-March-2020), after cutting green foliage stage and burning foliage (Dec-2019), during ten days. Also was measure the growth rate of the shoots to human consume. 
On the other hand, during all the first life production cycle of plants, 35 plants of each treatment were randomly collected in order to measure plant height, on monthly basis. At final of branch growth stage $(\mathrm{Nov} / 2019)=365$ days after sowed (das), the nitrates content in sap $\left(\mathrm{N}-\mathrm{NO}_{3} \mathrm{mg} / \mathrm{mL}^{-1}\right.$ of sap) was obtained by means of the procedure from Coombs et al. (1988). In the same phenological stage (365 das), root length and fresh weight (both considering the crown) by plant were determined. The length of the plants (from the crown apical) and root system were measure using a hand scale micrometer (General, 143, General Tools, Manufacturing Co., Inc. New York, USA). For all the above variables, we considered five replicates per treatment. In this stage, we collected five plants per treatment, to be sectioned in three parts, obtaining root, stem and above-ground portion.

After cutting green foliage and burning foliage (Dec-2019), in harvest of shoots to consume in the aboveground portion we assayed proteins, carbohydrates, total lipids, and ashes content. Proteins were assayed by the micro-Kjeldahl method, ashes by difference of weight burning the sample for $24 \mathrm{~h}$ at $500{ }^{\circ} \mathrm{C}$, total lipids were assayed according to Barnes and Blackstock (1973). Non-fibrous carbohydrates were determined according to Sato et al. (1998). Determination of Vitamin C by iodine titration was calculated according to Helmenstine (2020) in shoots to consume. For determination of sodium, potassium and chloride in shoots tissue to consume, we prepared extracts by grinding about $1 \mathrm{~g}$ with distilled water $(10 \mathrm{~mL})$ at $25^{\circ} \mathrm{C}$ for $10 \mathrm{~min}$. The homogenate was centrifuged at $3000 \times \mathrm{g}$ for $15 \mathrm{~min}$, and the supernatant filtered through qualitative filter paper. An aliquot of filtrate was used for $\mathrm{Na}^{+}$and $\mathrm{K}^{+}$determination by flame photometry and $\mathrm{Cl}^{-}$by precipitation titration with silver nitrate by Mohr's method.

The previously outlined variables were analyzed applying the procedure of Analysis of Variance (ANOVA), and a test of $\mathrm{F}$ to determine the statistical difference (Snedecor, 1956). The data from harvest of shoots (growth rate, dampness, proteins, ashes, and fatty acids) were analyzed after transforming values to arcsin values (Sokal and Rohfl, 1988). The least significant difference was estimated by Duncan's Multiple Range test at $\mathrm{P}=0.05$. The statistical tests were performed through the SAS computer program (SAS, 1996).

\section{Results and Discussion}

\section{Chitosan yield obtained from shrimp exoskeletons}

Based on the equation previously indicated in methodology, the overall yield of chitosan extracted from shrimp exoskeletons was developed; It was started with $154.63 \mathrm{~g}$ of shrimp exoskeleton sample from which after the process was carried out, $81.22 \mathrm{~g}$ of dry chitosan was obtained as the final product, obtaining a yield of $52.5 \%$. This yield obtained in the chitosan extraction process, when is compared with authors such as Hernández et al. (2009), De la Paz et al. (2012) and Vargas and Taquez (2018), show that the extraction process is an effective method where a percentage of obtaining can be obtained with an efficient synthetic transformation (Hernández et al., 2009). There are factors that influence in the chitosan yields, which are the raw material, the method used, the temperature, reaction time and concentration of the solvents (Covas, 2006; Hernández et al., 2009); so, the method used in the present study can be considered optimal for the effective obtaining of chitosan from marine sources. Likewise, it has been reported that chitin and chitosan yields vary among species, being higher in crab and shrimp (López-Corona et al., 2019a). Chitosan generally represents about 70\% of the chitin of the species (Mármol et al., 2004; Covas, 2006; Neith, 2010).

\section{Emergence of plants}

Evaluation of the plants $\left(\mathrm{tm} / \mathrm{m}^{-1}\right)$ emerged showed that all treatments answered between 14 and 21 days for maximum emergency (Table 5). The mixture and individual form of Bacillus amyloliquefaciens $(\mathrm{Ba})$ and quitosano (QUI), affected positively $(\mathrm{P}<0.05)$ the percentage emergency compared with control. However, those treatments based on mixtures of $\mathrm{Ba}$ and QUI stood-out vs individual form. Also was observed that among $\mathrm{CFU} / \mathrm{mL}$ concentrations, numerically the high values were to $1 \times 10^{8}$ and between concentrations of QUI, 
excelled those treatments about $100 \%$; in this last both treatments results were without significance $(\mathrm{P}<0.05)$. According to emergency rate, var. Early California of asparagus was improved for the mixtures of $\mathrm{Ba}$ and QUI, detecting that $\mathrm{Ba} 1 \times 10^{10} \mathrm{CFU} / \mathrm{mL}+\mathrm{QUI}$ concentration $50 \%$ and $\mathrm{Ba} 1 \times 10^{8} \mathrm{CFU} / \mathrm{mL}+\mathrm{QUI}$ concentration $100 \%$, showed at 4 das, the first $\mathrm{tm}^{-1}$ emerged $\left(18 \% \mathrm{tm} / \mathrm{m}^{-1} \pm 2\right.$.), while at 5 das, treatments of Ba and QUI in individual form were the $2 \mathrm{nd}$ treatments team with plants emerged $\left(12 \% \mathrm{tm} / \mathrm{m}^{-1} \pm 2\right)$; control treatment showed it's emerged new plants till to 7 das $\left(12 \% \mathrm{tm} / \mathrm{m}^{-1} \pm 2\right)$. A similar behavior was visualized for the treatments in the subsequent three evaluations ( 7 and 10 das), where the mixture of Ba and QUI with all and different concentrations, they showed a $100 \% \mathrm{tm} / \mathrm{m}^{-1} \pm 2$. Fit in mention one observation, that $\mathrm{Ba} 1 \times 10^{10}$ $\mathrm{CFU} / \mathrm{mL}+\mathrm{QUI}$ concentration $50 \%$ and $\mathrm{Ba} 1 \times 10^{8} \mathrm{CFU} / \mathrm{mL}+$ QUI concentration $100 \%$, had a behavior more quickly in comparison with $\mathrm{Ba} 1 \times 10^{8} \mathrm{CFU} / \mathrm{mL}+$ QUI concentration $50 \%$ and $\mathrm{Ba} 1 \times 10^{10} \mathrm{CFU} / \mathrm{mL}+$ QUI concentration 100\%. In the next evaluation (13 das), individual treatments based on $\mathrm{Ba}$ and QUI, reached $100 \% \mathrm{tmm}^{-1} \pm 2$, while control treatment shows it $100 \%$ of $\mathrm{tm} / \mathrm{m}^{-1} \pm 2$ at 21 das.

Table 5. Emergence (\%), nitrates in sap, plant height, length root and fresh matter of root and crown by the effect of halo-Bacillus amyloliquefaciens (Ba) as a PGPB and chitosan (QUI) in the indigenous area "Seris" under Sonora desert conditions

\begin{tabular}{|c|c|c|c|c|c|c|}
\hline \multirow{2}{*}{$\begin{array}{l}\text { Inoculant } \\
\text { [Bacterium] }\end{array}$} & \multirow{2}{*}{$\begin{array}{c}\text { Emergency } \\
(\%)\end{array}$} & \multirow[t]{2}{*}{$\mathrm{NO}_{3}\left(\mathrm{mg} / \mathrm{mL}^{-1}\right)^{*}$} & \multirow{2}{*}{$\begin{array}{l}\text { High plant } \\
\qquad(\mathrm{cm})^{*}\end{array}$} & Fresh matter & \multirow[t]{2}{*}{ Length root $(\mathrm{cm})^{*}$} & \multirow{2}{*}{$\begin{array}{c}\text { Fresh matter of root } \\
\text { and crown }\end{array}$} \\
\hline & & & & $(\mathrm{g} / \text { aerial plant })^{*}$ & & \\
\hline $\begin{array}{l}\text { 1.Ba concentration } 1 \\
\times 10^{8} \mathrm{CFU}^{\prime} \mathrm{mL}\end{array}$ & $85.0 \pm 3.2 \mathrm{ab}$ & $23.13 \pm 0.86 \mathrm{de}$ & $194.22 \pm 28.11 \mathrm{a}$ & $5611 \pm 111 \mathrm{c}$ & $26.10 \pm 3.2 b$ & $500 \pm 128 \mathrm{ab}$ \\
\hline $\begin{array}{l}\text { 2.Ba concentration } 1 \\
\times 10^{10} \mathrm{CFU}^{\prime} \mathrm{mL}\end{array}$ & $95.4 \pm 7.6 \mathrm{a}$ & $26.5 \pm 0.43 c$ & $187.50 \pm 23.39 \mathrm{a}$ & $5912 \pm 176 b c$ & $24.56 \pm 3.2 \mathrm{~b}$ & $510 \pm 145 \mathrm{ab}$ \\
\hline $\begin{array}{l}\text { 3.QUI } \\
\text { concentration } 50 \%\end{array}$ & $93.6 \pm 6.0 \mathrm{a}$ & $28.03 \pm 0.33 b$ & $186.69 \pm 12.71 \mathrm{a}$ & $5892 \pm 134 c$ & $27.47 \pm 2.5 b$ & $580 \pm 178 \mathrm{ab}$ \\
\hline $\begin{array}{l}\text { 4.QUI } \\
\text { concentration } 100 \%\end{array}$ & $90.2 \pm 3.5 \mathrm{ab}$ & $24.97 \pm 0.54 \mathrm{~d}$ & $189.18 \pm .13 .10 \mathrm{a}$ & $5654 \pm 101 c$ & $26.93 \pm 2.9 b$ & $545 \pm 110 \mathrm{ab}$ \\
\hline 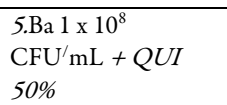 & $100 \mathrm{a}$ & $31.70 \pm 0.23 \mathrm{a}$ & $193.64 \pm 14.91 \mathrm{a}$ & $6298 \pm 127 b$ & $35.27 \pm 4.8 \mathrm{a}$ & $628 \pm 118 a$ \\
\hline $\begin{array}{l}6 . \mathrm{Ba} 1 \times 10^{10} \\
\mathrm{CFU}^{\prime} \mathrm{mL}+Q U I \\
50 \%\end{array}$ & $100 \mathrm{a}$ & $31.93 \pm 0.86 \mathrm{a}$ & $194.22 \pm 19.50 \mathrm{a}$ & $6800 \pm 121 \mathrm{a}$ & $38.10 \pm 3.2 \mathrm{a}$ & $640 \pm 132 \mathrm{a}$ \\
\hline $\begin{array}{l}7 . \mathrm{Ba} 1 \times 10^{8} \\
\mathrm{CFU}^{\prime} \mathrm{mL}+Q U I \\
100 \%\end{array}$ & $100 \mathrm{a}$ & $30.50 \pm 0.43 \mathrm{a}$ & $197.50 \pm 21.30 \mathrm{a}$ & $6102 \pm 90 \mathrm{~b}$ & $36.56 \pm 5.2 \mathrm{a}$ & $612 \pm 145 a$ \\
\hline $\begin{array}{l}8 . \mathrm{Ba} 1 \times 10^{10} \\
\mathrm{CFU}^{\prime} \mathrm{mL}+Q U I \\
100 \%\end{array}$ & $100 \mathrm{a}$ & $31.03 \pm 0.33 \mathrm{a}$ & $195.69 \pm 12.60 \mathrm{a}$ & $6210 \pm 108 b$ & $35.47 \pm 4.2 \mathrm{a}$ & $620 \pm 102 a$ \\
\hline 9. Control & $85 \pm 3.5 \mathrm{ab}$ & $20.17 \pm 0.14 \mathrm{f}$ & $180.18 \pm .22 .15 \mathrm{a}$ & $3945 \pm 93 d$ & $23.93 \pm 7.1 \mathrm{c}$ & $395 \pm 101 \mathrm{bc}$ \\
\hline
\end{tabular}

Control: non treated with QUI and Ba. Sap $\left(\mathrm{NO}_{3}\right)$ at final of side branch growth (July-Nov/2019); *: variable evaluated in side branch growth stage (July-Nov/2019) - 365 days after sowed. Averages with the same literal column indicate that there are no significant differences $(\mathrm{P}>0.05)$.

Currently, food production in arid or desert areas is a critical factor, since yields and fruit quality is impaired, and in this sense of select nutrient supplies will negatively or positively impact human health and fertility of soils, mainly. Plant growth-promoting bacteria (PGPB) and chitosan (QUI) often have many strategies to deal with adverse factors. In dry arid and desert areas, this PGPB and QUI can be used to improve the growth of plants high temperatures and salinity soils.

In our research, in this previously variable (plants emerged rate and \%), the study of this biofertilizers like a $\mathrm{Ba}$ as a PGPB and the chitosan as a bio derivative from crustacean exoskeletons, showed in asparagus var. Early California the ability to promote the emergency rate. Blackmar and Mallarino (1996), mention that Ba as a PGPB has the ability to produce or stimulate synthesis of hormones such as indole acetic acid or gibberellin (GA3). For its part Arora et al. (2017), mention that the application of this type of biofertilizer (Ba) could also have stimulated some stages in plant growth through the biological fixation of nitrogen, solubilization of 
phosphates and the production of phytohormones. Same authors indicate that one critical stage where PGPB helps is in germination and emergence of seedlings under open field, because there are phytopathogenic microorganisms that attack the root and the production of hydrolytic enzymes from PGPB can act as biological control, production of extracellular polysaccharides, systematic induced and / or acquired resistance. According to chitosan, it is a biopolymer with a high molecular weight linear ranging from 10,000 to 1,000,000 Dalton. It is a biodegradable, non-toxic, biocompatible, semi-permeable compound with great properties. All the characteristics of chitosan in addition to its positive charge, gives it potential applications in various fields (Xu et al., 2008), in addition to the multiple biological properties that have been attributed to it, such as antimicrobial, antioxidant, anti-inflammatory, antifungal, among others (Devlieghere et al., 2004; Hewajulige et al., 2007; Liu et al., 2007). In recent studies, chitosan has been used as a biofertilizer in different types of crops such as corn (Peña et al., 2016), tobacco (González-Gómez et al., 2017), rice (Molina et al., 2017), the orchid (Vera and Parismoreno, 2017), improving the germination process, rooting, plant foliage production, harvest yields and micronutrient adsorption and stimulating the defense mechanism of plants and formation of physical barriers (Bernadette, 2014; Hadwiger et al., 1984). Our results where the QUI favored the rate of emergence of plants as well as those previously indicated by different authors are evidence that the presence of chitosan plays a role in growth and development at different vegetative stages, such as emergency, of diverse plants (Bagwell et al., 2001). Nithin et al. (2020) revealed that cultivation of strawberry variety "winter dawn" by application of chitosan found better for increasing vegetative growth, yield attributing traits and yield under naturally ventilated polygreenhouse.

\section{Plant height and sap, and length root and fresh matter of root and crown}

While the plants were growing in all plants of all treatments, the next stage of the asparagus "unproductive phase" was present during one year in each plant (Table 3); in this stage are formed shoots that aren't harvested, but are allowed to expand vegetatively; specifically, there is side branch growth. In this period, the preparation of reserve substances will take place, which will be accumulated later in flowering and fruiting. To verify the amount of reserve in the plants, we evaluate the sap in plants of each treatment. Results shows in Table 5 where a similar behavior as an emergency of plants were observed. In this $\mathrm{N}-\mathrm{NO} 3 \mathrm{mg} / \mathrm{mL}^{-1}$ in sap variable the mixture and individual form of $\mathrm{Ba}$ and $\mathrm{QUI}$, showed significantly exceeded $(\mathrm{P}<0.05)$ vs control. The best values $\left(30.07-32.79 \mathrm{~N}-\mathrm{NO}_{3} \mathrm{mg} / \mathrm{mL}^{-1}\right)$ were with the interaction between $\mathrm{Ba}$ and QUI in their different concentrations while control shows lower values of $20.17 \pm 0.14$.

In the context of reserves, they are important to give vigour to a plant from an eco-physiological point of view under dry and desert conditions, for the case of the final height variable evaluated, after 365 days after sowed (das), results show null existence of significant differences between treatments (Table 5). We can see that numerically; the highest values are appreciated in the treatments that were subjected to Ba and QUI vs control treatment (197.50 vs 180.18). Although in height plant variable the reserves appreciated in sap had no significance, in fresh matter per plant, length root and fresh matter of root and crown $(=$ rhizome $=$ where the nutritive substances are stored in the fleshy roots for their subsequent productive stage of shoots for human consumption) variables, it was seen reflected between treatments significant differences with $\mathrm{P}<0.05$. Results showed between treatments the high values were to $\mathrm{Ba} 1 \times 10^{10} \mathrm{CFU} / \mathrm{mL}+\mathrm{QUI} 50 \%$; in fresh matter $(6800$ $\mathrm{g} \pm 121)$, length root $(38.10 \mathrm{~cm} \pm 3.2)$ and fresh matter of root and crown $(640 \mathrm{~g} \pm 132)$ while control treatment showed reduced values $(3945 \mathrm{~g} \pm 93,23.93 \mathrm{~cm} \pm 7.1 \mathrm{~g}$ and $395 \pm 101$ ), respectively (Table 5$)$. One of the main organs that is responsible for strengthening the plant through the uptake-absorption of nutrients and their translocation, is the rhizosphere of plants. The rhizosphere is the narrow zone of nutrient-rich soil that surrounds the root system of the species plants where complex biological and ecological processes take place; it is a very favorable habitat for the proliferation of microorganisms that thrive in the exudates (sugars, amino acids and other metabolites secondary) that are absorbed as nutrients by the microorganisms in the rhizodeposit and that have a significant impact on plant health and soil fertility (Bais et al., 2006; Ahmed et al., 2017; Tabassum et al., 2017). However, when the bad conditions in dry arid and desert area are present, 
farmer's need to make a profitable agriculture, an agriculture that currently is demand is sustainable form. our results are consistent with those conclusions that show that PGPB-based bioinoculants stimulate growth, development and performance of vegetable crops; these effects are attributed to different mechanisms of action: (i) bioprotective, reduce damage caused by pathogens; (ii) biofertilizers, improve the acquisition of nutritional elements; (iii) biostimulant, production of phytohormones. The greatest advances have been reported with those genera where Bacillus, Paenibacillus, Streptomyces, Pseudomonas, Burkholderia and Agrobacterium appear (Ince and Ince, 2017). To another part, various reports shows that plants treated with chitosan show better characteristics (Hadwiger et al., 1984; Reddy et al., 1999; Guan et al., 2009), this thanks to the beneficial effects of chitosan in the synthesis, degradation and translocation of fat and carbohydrate biomolecules (Cheah et al., 1997; Reddy et al., 1999; Ruan and Xue, 2002; Zhou et al., 2002; Shao et al., 2005), in addition to actively influencing the defense response of the plant, the release of nutrients and protecting from microbial damage (Dima et al., 2017).

\section{Growth rate and proximal analysis (moisture, carbohydrates, protein, lipids, $\mathrm{K}^{+}, \mathrm{Na}^{+}$and $\mathrm{Vit} \mathrm{C}$ ) content in harvest of shoots to consume}

Results of variables previously described reflect how the biofertilizers studied, help asparagus var. Early California to produce the greatest possible amount of nutritive substances, that were stored in the fleshy roots (root and crown); this rhizome favored by Ba and QUI will grow continuously, reaching a large size that will influence the appearance of the new asparagus or "shoots" that constitute the edible part of the plant. In this sense, after 450 days after sowed, was detected $30 \pm 2$ crown's $/ \mathrm{m}^{-1}$, with the exception of control treatment which showed $27 \pm 2$ crown' $\mathrm{s} / \mathrm{m}^{-1}$; fit in mention that considering double row, the results for the biotreatment's shows $60 \pm 4$ crown's $/ \mathrm{m}^{-1}$, with a distance between rows of $40 \mathrm{~cm}$, while to control was $54 \pm 4$ crown' $\mathrm{s} / \mathrm{m}^{-1}$ without significance differences with $\mathrm{P}<0.05$. According the emergence rate of this shoots to human consume, results indicated that mixture and individual form of Bacillus amyloliquefaciens $(\mathrm{Ba})$ and quitosano (QUI), affected positively $(\mathrm{P}<0.05)$ compared with control. Results indicate that mixtures of biofertilizers at different concentrations at $8 \pm 2$ days after burning (dab), rhizomes show first shoots emerged, while control was till to $12 \pm 3 \mathrm{dab}$; treatments with $\mathrm{Ba}$ and QUI in separate form, promoted the emergence of shoot between $10 \pm 3 \mathrm{dab}$. The results also show that those treatments where $\mathrm{Ba}$ and Qui were present (independently in mixture or individual form), each crown produced between 8 to 12 shoots; the opposite occurred with the control where up to $6 \pm 2$ shoots $/ \mathrm{m}^{-1}$ were counted, being able to count the production per ha $\left(\mathrm{kg} / \mathrm{ha}^{-1}\right)($ Table 6$)$.

Subsequently from the emergence of shoots to human consume variable, these vegetative parts showed a quickly developing daily when they were evaluated in the rate of growth of the shoots; results with $\mathrm{P}<0.05$ were obtained $(7.62 \mathrm{~cm} /$ day \pm 0.59 in those treatments with mixture of $\mathrm{Ba}$ and QUI; for its part in separate form of Ba and QUI treatments, the rate of growth of the shoots was $7.09 \mathrm{~cm} /$ day \pm 0.71 , while in control treatment was $5.01 \mathrm{~cm} /$ day \pm 0.15$)$.

The international market demands that shoots have a length of $22 \mathrm{~cm}$ and a weight of $30 \mathrm{~g} / \mathrm{shoot}$. This measure was reached on the third day in those treatments based on Ba and QUI (mixtures in different concentrations and individual form), while the control treatment reached these units after 5 days \pm 1 . Due the harvest of shoots is from January to March (Table 3), this velocity (rate of shoots to human consume), is obtained considering some factors: substances of reserve and nutrients present in the rhizome (synthesized during the vegetative phase), and temperature of the soil (generated in the burning foliage stage, achieving temperatures in the soil until $70{ }^{\circ} \mathrm{C} \pm 4$ ), and the environmental temperature in the harvest of shoots to consume period $\left(38 \pm 3^{\circ} \mathrm{C}\right)$. Other factors that played an important role were $\mathrm{Hr}$, photosynthetically active radiation (Rfa: me/ $\mathrm{M}^{-2} \mathrm{~s}^{-1}$ ) and insolation (Ima h/day), present in this study with var. Early California of asparagus under field conditions (Table 3). However, in the present study it's appreciated that the production of shoots for human consumption, was positively affected by Ba and QUI in their different concentrations and formulation (Table 6). With data obtained of emergence of shoots for human consumption, the best treatment 
until the end of the harvest period, in kg. $\mathrm{m}^{-1}$ and $\mathrm{kg} / \mathrm{ha}^{-1}$ variables were those treatment biofertilized with $\mathrm{Ba}$ and Qui (mixtures and individual form); control treatment showed the lowest values with $\mathrm{P}<0.05$ (Table 6). In relation with proximal analysis (moisture, carbohydrates, protein, lipids, $\mathrm{K}+\mathrm{Na}+$ and $\mathrm{Vit} \mathrm{C}$ ), results showed significant differences between biotreated treatments vs control, with the exception of the $\mathrm{Na}^{+}$content. It was also appreciated that between mixtures and concentrations of Ba and QUI, they behaved in a similar way (Table 7). The treatment that stands out (numerically) from those biotreated is Ba $1 \times 10^{10} \mathrm{CFU} / \mathrm{mL}+$ QUI $100 \%$, compared with other treatments; the control treatment yielded the lowest values with $\mathrm{P}<0.05$.

Our results are evidence that the presence of beneficial microorganisms $(\mathrm{Ba})$ or biomolecules like QUI, plays a role in growth and development at different vegetative stages, such as emergency, of diverse plants that growth under extreme conditions (Blackmar and Mallarino, 1996; Bagwell et al., 2001). We cannot explain effect of Bacillus amyloliquefaciens on asparagus var. Early California. However, a similar effect was found in roots of other cultivars (Will and Sylvia, 1990), grass and rice (Haathela et al., 1986). The phenomenon seems to be related to the ability of Bacillus amyloliquefaciens to produce growth promoting substances. Those results are in agree with the increased shoot growth of sea oats Uniola paniculata L. after inoculation with Bacillus amyloliquefaciens (Will and Sylvia, 1990). According to Vit C, our results are in agree with those obtained by Khan et al. (2002) and Chibu and Shibayama (2003) when applying the concentration of chitosan.

Table 6. Yield and production of harvest of shoots to consume by the effect of halo-Bacillus amyloliquefaciens $(\mathrm{Ba})$ as a PGPB and chitosan (QUI) in the indigenous area "Seris" under Sonora desert conditions

\begin{tabular}{|c|c|c|c|c|c|}
\hline & Treatments & $\begin{array}{c}\text { \# shoots } \\
\text { shoots } / \mathrm{m}^{-1}\end{array}$ & $\mathrm{~g} /$ shoot $^{*}+$ & ${ }^{*} \mathrm{~kg} / \mathrm{m}^{-1}$ & ${ }^{*} \mathrm{~kg} / \mathrm{ha}^{-1}$ \\
\hline 12. & Ba concentration $1 \times 10^{8} \mathrm{CFU} / \mathrm{mL}$ & $710 \pm 33 \mathrm{ab}$ & $29 \pm 3 \mathrm{a}$ & $20.590 \mathrm{a}$ & $7,100 \pm 33 a$ \\
\hline 13. & Ba concentration $1 \times 10^{10} \mathrm{CFU} / \mathrm{mL}$ & $704 \pm 42 \mathrm{ab}$ & $30 \pm 2 \mathrm{a}$ & $21.120 \mathrm{a}$ & $7,040 \pm 42 \mathrm{a}$ \\
\hline 14. & QUI concentration $50 \%$ & $697 \pm 23 \mathrm{ab}$ & $29 \pm 3 \mathrm{a}$ & $20.213 \mathrm{a}$ & $6,970 \pm 23 a$ \\
\hline 15. & QUIconcentration $100 \%$ & $689 \pm 22 \mathrm{ab}$ & $29 \pm 3 \mathrm{a}$ & $19.981 \mathrm{a}$ & $6,890 \pm 22 a$ \\
\hline 16. & $\mathrm{Ba} 1 \times 10^{8} \mathrm{CFU} / \mathrm{mL}+$ QUI 50\% & $753 \pm 37 \mathrm{a}$ & $30 \pm 2 \mathrm{a}$ & $22.590 \mathrm{a}$ & $7,530 \pm 37 a$ \\
\hline 17. & $\mathrm{Ba} 1 \times 10^{10} \mathrm{CFU} / \mathrm{mL}+$ QUI $50 \%$ & $750 \pm 41 \mathrm{a}$ & $30 \pm 2 \mathrm{a}$ & $22.500 \mathrm{a}$ & $7,500 \pm 41 \mathrm{a}$ \\
\hline 18. & $\mathrm{Ba} 1 \times 10^{8} \mathrm{CFU} / \mathrm{mL}+$ QUI $100 \%$ & $755 \pm 42 \mathrm{a}$ & $30 \pm 2 \mathrm{a}$ & $22.650 \mathrm{a}$ & $7,550 \pm 42 \mathrm{a}$ \\
\hline 19. & $\mathrm{Ba} 1 \times 10^{10} \mathrm{CFU} / \mathrm{mL}+Q U I 100 \%$ & $748 \pm 33 \mathrm{a}$ & $30 \pm 2 \mathrm{a}$ & $22.440 \mathrm{a}$ & $7,480 \pm 33 a$ \\
\hline 20. & Control & $613 \pm 37 c$ & $23 \pm 4 b$ & $14.099 \mathrm{~b}$ & $6,130 \pm 37 \mathrm{~b}$ \\
\hline
\end{tabular}

Control: non treated with QUI and Ba. Variables evaluated in harvest of shoots to consume (January-March-2020)* Averages with the same literal column indicate that there are no significant differences $(\mathrm{P}>0.05)$. + variable evaluated 3 days after emerging from the crown

Table 7. Proximal analysis (moisture, carbohydrates, protein, lipids, $\mathrm{K}^{+}, \mathrm{Na}^{+}$and $\mathrm{Vit} \mathrm{C}$ ) content in harvest of shoots to consume by the effect of halo-Bacillus amyloliquefaciens $(\mathrm{Ba})$ as a PGPB and chitosan (QUI) in the indigenous area "Seris" under Sonora desert conditions

\begin{tabular}{|l|l|l|l|l|l|l|l|}
\hline \multicolumn{1}{|c|}{ Treatments } & $\begin{array}{c}\mathrm{COOH}^{*+} \\
\mathrm{g}\end{array}$ & $\begin{array}{c}\text { Protein }^{*+} \\
\mathrm{g}\end{array}$ & $\begin{array}{c}\text { Humidity } \\
(\%)\end{array}$ & $\begin{array}{c}\mathrm{Lipids}^{*+} \\
(\mathrm{mg} / \mathrm{g})\end{array}$ & $\begin{array}{c}\mathrm{K}^{++} \\
\mathrm{mg}\end{array}$ & $\begin{array}{c}\mathrm{Na}^{++} \\
\mathrm{mg}\end{array}$ & $\begin{array}{c}\mathrm{VitC}^{*+} \\
\mathrm{mg}\end{array}$ \\
\hline Ba concentration $1 \times 10^{8} \mathrm{CFU} / \mathrm{mL}$ & $3.9 \pm .4 \mathrm{ab}$ & $2.7 \pm .4 \mathrm{a}$ & $4.55 \pm .14 \mathrm{a}$ & $0.1 \pm .03 \mathrm{~b}$ & $206 \pm 5 \mathrm{a}$ & $2.00 \pm .4 \mathrm{a}$ & $5.36 \pm .20 \mathrm{a}$ \\
\hline Ba concentration $1 \times 10^{10} \mathrm{CFU} / \mathrm{mL}$ & $3.8 \pm .4 \mathrm{ab}$ & $2.6 \pm .2 \mathrm{a}$ & $4.01 \pm .24 \mathrm{a}$ & $0.1 \pm .02 \mathrm{~b}$ & $203 \pm 4 \mathrm{a}$ & $2.01 \pm .2 \mathrm{a}$ & $5.56 \pm .24 \mathrm{a}$ \\
\hline QUIconcentration $50 \%$ & $3.7 \pm .4 \mathrm{ab}$ & $2.5 \pm .2 \mathrm{a}$ & $4.29 \pm .22 \mathrm{a}$ & $0.1 \pm .01 \mathrm{~b}$ & $201 \pm 7 \mathrm{a}$ & $2.09 \pm .3 \mathrm{a}$ & $5.46 \pm .22 \mathrm{a}$ \\
\hline QUIconcentration $100 \%$ & $3.7 \pm .3 \mathrm{ab}$ & $2.6 \pm .3 \mathrm{a}$ & $4.02 \pm .10 \mathrm{a}$ & $0.1 \pm .03 \mathrm{~b}$ & $199 \pm 7 \mathrm{a}$ & $2.01 \pm .4 \mathrm{a}$ & $5.36 \pm .33 \mathrm{a}$ \\
\hline $\mathrm{Ba} 1 \times 10^{8} \mathrm{CFU} / \mathrm{mL}+$ QUI $50 \%$ & $3.9 \pm .3 \mathrm{a}$ & $2.7 \pm .4 \mathrm{a}$ & $4.65 \pm .22 \mathrm{a}$ & $0.1 \pm .01 \mathrm{~b}$ & $202 \pm 4 \mathrm{a}$ & $2.04 \pm .2 \mathrm{a}$ & $5.16 \pm .21 \mathrm{a}$ \\
\hline $\mathrm{Ba} 1 \times 10^{10} \mathrm{CFU} / \mathrm{mL}+$ QUI $50 \%$ & $4.1 \pm .3 \mathrm{a}$ & $2.6 \pm .4 \mathrm{a}$ & $4.22 \pm .33 \mathrm{a}$ & $0.1 \pm .01 \mathrm{~b}$ & $209 \pm 9 \mathrm{a}$ & $2.03 \pm .5 \mathrm{a}$ & $5.22 \pm .17 \mathrm{a}$ \\
\hline $\mathrm{Ba} 1 \times 10^{8} \mathrm{CFU} / \mathrm{mL}+$ QUI $100 \%$ & $3.9 \pm .4 \mathrm{a}$ & $2.7 \pm .3 \mathrm{a}$ & $4.35 \pm .12 \mathrm{a}$ & $0.1 \pm .03 \mathrm{~b}$ & $207 \pm 11 \mathrm{a}$ & $2.02 \pm .4 \mathrm{a}$ & $5.55 \pm 22 \mathrm{a}$ \\
\hline $\mathrm{Ba} 1 \times 10^{10} \mathrm{CFU} / \mathrm{mL}+$ QUI $100 \%$ & $4.0 \pm .4 \mathrm{a}$ & $2.8 \pm .3 \mathrm{a}$ & $4.73 \pm .21 \mathrm{a}$ & $0.1 \pm .02 \mathrm{~b}$ & $210 \pm 4 \mathrm{a}$ & $1.99 \pm .3 \mathrm{a}$ & $5.60 \pm 18 \mathrm{a}$ \\
\hline Control & $3.2 \pm 4 \mathrm{bc}$ & $1.9 \pm .4 \mathrm{~b}$ & $3.15 \pm .45 \mathrm{~b}$ & $0.2 \pm .03 \mathrm{a}$ & $193 \pm 4 \mathrm{~b}$ & $2.6 \pm .4 \mathrm{a}$ & $4.79 \pm .12 \mathrm{~b}$ \\
\hline
\end{tabular}

Control: non treated with QUI and Ba. Variables evaluated in harvest of shoots to consume (January-March-2020)* Averages with the same literal column indicate that there are no significant differences $(\mathrm{P}>0.05)$. + variable evaluated 3 days after emerging from the crown 
Also, Reyes et al. (2020) obtained best results in the variables plant height and yield components when applying the chitosan. However, the biochemical indicators of tomato fruit quality and its mineral content did not show differences with the application of chitosan.

The increase in fruit length, diameter and volume might be due to oscillation of physiochemical status of the plant and production of more photosynthates due to maximum vegetative growth of plants as influenced by the foliar application of chitosan (ElMiniawy et al., 2013). The current results are in accordance with the findings of Shehata et al. (2012) on cucumber and Abdel-Mawgoud et al. (2010) on strawberry.

The influence of the environment on living organisms is the sum of each and every one of the environmental factors. These factors determine adaptations, a wide variety of plant and animal species, and the distribution of living organisms on Earth. Although it is true that the environmental conditions in the Sonoran Desert (Table 3) are extreme for conventional crops, in our study with the evaluated biofertilizers (Ba and QUI), it was observed that in asparagus were reduced the effect of abiotic adversities. Most of the variables evaluated reveal higher values compared with the control treatment, specifically yield production and nutritional values variables in shoots for human consumption, which is an indication of how the asparagus treated with Ba and QUI reacted as living body for photosynthesis and hydrolytic processes, such as the breakdown of starch into sugar. Moreover, other probable reasons for increase in vegetative growth parameters could be attributed to an increase in the availability and uptake of water and essential nutrients through adjusting cell osmotic pressure and reducing the accumulation of harmful free radicals by increasing antioxidants and enzyme activities (Guan et al., 2009). Likewise, in recent studies, the content of protein, fiber and total ash has been reported for other plants (Beltrán et al., 2017), and although in the present study was not analyzed in green matter, asparagus could play a new role in the formulation of food for marine animals like a shrimp and fish, due to the high content of protein and fiber, an aspect that makes it comparable to other flours such as wheat (Madrid, 1988).

\section{Conclusions}

In the present study, Bacillus amyloliquefaciens (Ba) and chitosan (QUI) in synergy, positively influenced vegetative development, yields and nutritional attributes (emergency, high plant, fresh matter, length root, fresh matter of root and crown and shoots $\mathrm{kg} / \mathrm{m}^{-1}$ ) in Asparagus officinalis of shoots for human consumption. Under the established field conditions, the inoculation agreement of $\mathrm{Ba}$ and QUI increased the emergence rate, nitrates in sap, fresh and root weight and crown, and its subsequent production of shoots for human consumption (emergence rate, proximal values such as protein, lipids and carbohydrates, in addition to $\mathrm{K}+$ and Vit $\mathrm{C}$ ) compared with the control. The above indicates the biostimulant effect of Ba and QUI improve the quality in var. Early California in the indigenous area "Seris" under Sonora desert conditions. However, studies related to the promotion of plants of the following phenological stages of Asparagus should be considered in further studies. This is the first report of the beneficial halobacteria and chitosan with a promoter effect in asparagus crop under desert conditions.

\section{Authors' Contributions}

Conceptualization: JOG, RJHP, EORP; Methodology: PPR, RRGE, EORP; Validation: GZS, JMNS, EORP; Formal analysis: PPR, EORP; Investigation: JOG, EORP; Data curation: EORP, PPR; Funding acquisition: EORP; Project administration: EORP; Writing: EORP, PPR; Review and editing: PPR, EORP. All authors read and approved the final manuscript. 


\section{Acknowledgements}

The authors are grateful to Comcaac indigenous community and the Academic Body: bioprocesses and agri-food systems Degree of consolidation of the Department of Research and Postgraduate in Foods of the University of Sonora / Technical collaboration in diagnostics of bioprocesses of agronomic and silvopastoril production systems under desert coastal environments.

\section{Conflict of Interests}

The authors declare that there are no conflicts of interest related to this article.

\section{References}

Abdel-Mawgoud AMR, Tantawy TA, El-Nemr MA, Sassine YN (2010). Growth and yield responses of strawberry plants to chitosan application. European Journal of Scientific Research 39(1):170-177. https://www.researchgate.net/publication/287681481

Ahmed B, Zaidi A, Khan MS, Rizvi A, Saif S, Shahid M (2017). Perspectives of plant growth promoting rhizobacteria in growth enhancement and sustainable production of tomato. In: Zaidi A and Khan MS (Eds). Microbial Strategies for Vegetable Production. Cham, Switzerland: Springer Nature, pp 125-149. https://doi.org/10.1007/978-3-31954401-4_6

Arora NK, Verma M, Mishra J (2017). Rhizobial bioformulations: past, present and future rhizotrophs. Plant Growth Promotion to Bioremediation. Springer, pp 69-99. https://doi.org/10.1007/978-981-10-4862-3_4

Bagwell Ch, Dantzler M, Bergholz P, Lovell Ch (2001). Host-specific ecotype diversity of rhizoplane diazotrophs of the perennial glasswort Salicornia virginica and selected salt mash grasses. Journal Aquatic Microbiol Ecology 23:293300. https://doi.org/10.3354/AME023293

Bais HP, Weir TL, Perry LG, Gilroy S, Vivanco JM (2006). The role of root exudates in rhizosphere interactions with plants and other organisms. Annual Review of Plant Biology 57:233-266. https://doi.org/10.1146/

Barnes H, Blachstock J (1973). Estimation of lipids in marine animal and tissues: detailed investigation of sulphophosphovanil method for 'total' lipids. Journal of Experimental Marine Biology and Ecology 12:103-118. https://doi.org/10.1016/0022-0981(73)90040-3

Beltrán-Burboa C, Arce M, Bianciotto O, ... Rueda-Puente E (2017). Salicornia bigelovii (Torr.): A model system to be incorporated as an agricultural crop in arid-desert areas. Biotecnia 19:46-50. https://doi.org/10.18633/biotecnia.v19i0.413

Bernadette DJ (2014). Obtaining chitin and chitosan from exoskeletons of Patagonian crustaceans: characterization and applications. https://doi.org/10.5772/65258

Blackmar A, Mallarino A (1996). Physiological production stage prepared by research agronomists. In: Bredha J, Kreme R (Eds). Proyecto Agricultura de Precisión Manfredi. Dept. of Agronomy. Iowa State University, Ames.

Carrillo A, Puente M, Castellanos T, Bashan Y (1998). Aplicaciones Biotecnologicas de Ecologia Microbiana. [Biotechnological Applications of Microbial Ecology]. Manual de Laboratorio. Pontificia Universidad Javeriana, Santafé de Bogotá, Colombia- Centro de Investigaciones Biológicas del Noroeste La Paz, Baja California Sur, México, pp 51.

Cheah L, Page B, Shepherd R (1997). Chitosan coating for inhibition of Sclerotinia rot of carrots. New Zealand Journal of Crop and Horticultural Science 25(1):89-92. https://doi.org/10.1080/01140671.1997.9513992

Chibu H, Shibayama H (2003). Effects of chitosan application on the growth of several crops. In: Uragami T, Kurita K, Fukamizo T (Eds). Chitin and chitosan in life science. Yamaguchi, Japan, 235-239. https://agris.fao.org/agrissearch/search.do?recordID $=$ PH2002000023

Covas CA (2006). Estudios sobre quitina y quitosano. [Studies on chitin and chitosan]. Trabajo presentado para optar por el grado científico de Doctor en Ciencias. Universidad de La Habana - Cuba. https://www.redalyc.org/pdf/933/93310204.pdf 
De La Paz N, Fernández M, López O, Nogueira A, García C, Pérez D, Díaz D (2012). Optimización del proceso de obtención de quitosano derivada de quitina de langosta. [Optimization of the process for obtaining chitosan derived from lobster chitin]. Revista Iberoamericana de Polímeros 13(3):103-116. https://dialnet.unirioja.es/servlet/articulo?'codigo=7896914

Devlieghere F, Vermeulen A, Debevere J (2004). Chitosan: antimicrobial activity, interactions with food components and applicability as a coating on fruit and vegetables. Food Microbiology 21(6):703-714. https://doi.org/10.1016/j.fm.2004.02.008

Dima JB, Sequeiros C, Zaritzky N (2017). Síntesis de microesferas de quitosano para encapsular y liberar fertilizante. [Chitosan microsphere synthesis to encapsulate and release fertilizer]. In IV Jornadas de Investigación, Transferencia y Extensión de la Facultad de Ingeniería. Argentina. http://sedici.unlp.edu.ar/handle/10915/60402

Efe D (2020). Potential plant growth-promoting bacteria with heavy metal resistance. Current Microbiology https://doi.org/10.1007/s00284-020-02208-8

El-Miniawy SM, Ragab ME, Youssef SM, Metwally AA (2013). Response of strawberry plants to foliar spraying of chitosan. Research Journal of Agriculture and Biological Sciences 9(6):366-372. http://research.asu.edu.eg/handle/123456789/1979

González-Gómez L, Jiménez M, Vaquero L, Paz I, Falcón A, Araujo L (2017). Evaluation of the application of chitosan on tobacco seedlings (Nicotiana tabacum L.). Revista Centro Agrícola 44(1):34-40. http://scielo.sld.cu/scielo.php?script=sci_arttext\&pid=S0253-57852017000100005

Guan YJ, Hu J, Wang-Xian J, Shao-Chen X (2009). Seed priming with chitosan improves maize germination and seedling growth in relation to physiological changes under low temperature stress. Journal of Zhejiang University Science B 10(6):427-433. https://doi.org/10.1631/jzus.B0820373

Haahtela K, Ronkko R, Laaskso T, Williams P, Korhonen T (1990). Root-associated Enterobacter and Klebsiella in Poa pratensis: Characterization of an iron-scavening system and a subtance stimulating root hair production. Molecullar Plant-Microbe Interaction 3:358-365.

Hadwiger L, Fristenski B, Riggleman R (1984). Chitin, chitosan and related enzymes. In: Fikakis JP, Ed. Academic Press Inc., Orlando FL. https://www.elsevier.com/books/chitin-chitosan-and-related-enzymes/zikakis/978-0-12780950-2

Helmenstine AM (2020). Vitamin C determination by iodine titration. ThoughtCo, Aug. 27, 2020, thoughtco.com/vitamin-c-determination-by-iodine-titration-606322

Hernández C, Águila E, Flores O, Viveros E, Ramos E (2009). Obtaining and characterizing chitosan from shrimp exoskeletons. Superficies y Vacío 22(3):57-60. http://www.scielo.org.mx/pdf/sv/v22n3/v22n3a12.pdf

Hewajulige I, Sultanbawa Y, Wijeratnam R, Wijesundara R (2009). Mode of action of chitosan coating on anthracnose disease control in papaya. Phytoparasitica 37(5):437-444. https:// doi.org/10.1007/s12600-009-0052-5

Ince $M$, Ince OK (2017). An overview of adsorption technique for heavy metal removal from water/wastewater: a critical review. International Journal of Pure and Applied Sciences 3(2):10-19. https:// doi.org/10.29132/ijpas.358199

Jefferies R (1981). Osmotic adjustment and the response of halophytic plants to salinity. Bioscience 31:42-48. https://doi.org/10.2307/1308177

Kapulnik Y, Okon Y, Kigel J (1981). Effects of temperature, nitrogen fertilization and plant age on nitrogen fixation by Setaria italica inoculated with Azospirillum brasilense (strain cd). Plant Phisiology 68:340-343. https://doi.org/10.1104/pp.68.2.340

Khan MH, Singha KLB, Panda SK (2002). Changes in antioxidant levels in Oryza sativa L. roots subjected to $\mathrm{NaCl}$ salinity stress. Acta Physiologiae Plantarum 24:145-148. https:// doi.org/10.1007/BF02706630

Kathe R, Holger B, Pillen K, Rabenstein F, Nothnagel T (2019). Development of a bioassay to assess resistance to Fusarium oxysporum (Schlecht.) in asparagus (Asparagus officinalis L.). Journal of Phytopathology 167(10):558566. https://doi.org/10.1111/jph.12845

Liu J, Tian S, Meng X, Xu Y (2007). Effects of chitosan on control of postharvest diseases and physiological responses of tomato fruit. Postharvest Biology and Technology 44(3):300-306. https://agris.fao.org/agrissearch/search.do?recordID $=$ US201300768298

López-Corona BE, Mondaca I, Gortáres P, Peña J, Meza MJ, Balderas J, Vargas J, Rueda Puente EO (2019a). Technique of cutting in agriculture: an alternative at the vanguard. Tropical and Subtropical Agroecosystems 22(2). http://www.revista.ccba.uady.mx/urn:ISSN:1870-0462-tsaes.v22i2.2795 
López-Corona BE, Mondaca I, Gortáres P, Meza M, Balderas J, Rueda Puente E (2019b). Rooting of Salicornia bigelovii (Torr.) cuttings by chitosan as a by-product of marine origin. Terra Latinoamericana https://doi.org/10.28940/terra.v37i4.517

Madrid LA (1988). Utilización de la paja de halófitas en rumiantes. [Use of halophyte straw in ruminants]. II Congreso Nacional sobre Halófitas. Obregón, Sonora, pp 59-66. https://www.redalyc.org/pdf/1750/175021491002.pdf

Mármol Z, Gutiérrez E, Páez G, Ferrer J, Rincón M (2004). Thermoalkaline deacetylation of chitin from shrimp shells. Multiciencias 4(2):1-9. https://www.redalyc.org/pdf/904/90440203.pdf

Molina ZJ, Colina M, Rincón D, Vargas J (2017). Effect of the use of chitosan in the improvement of rice cultivation (Oryza sativa L. var. sd20a). Revista de Investigación Agraria y Ambiental 8(2):151-165. https://doi.org/10.22490/21456453.2041

Nahidh S, Hakeem A (1991). Response of wheat to dual inoculation with VA-Micorrhiza and Azospirillum, fertilized with NPK and irrigated with sewage effluent. Arid Soil Research and Rehabilitation 5:83-96. https://doi.org/10.1080/15324989109381269

Neith APL (2010). Biotechnological extraction of chitin for the production of chitosans: characterization and application. Food and Nutrition. Université Claude Bernard - Lyon I; Université autonome métropolitaine (Universidad Autónoma Metropolitana) (Iztapalapa). Español. https://tel.archives-ouvertes.fr/tel00807945/document

Nithin KM, Madaiah D, Dinesh KM, Dhananjaya BC, Shivakumar BS, Sahana BJ (2020). Effect of chitosan application on growth and yield attributes of strawberry (Fragaria $\times$ ananassa Duch.) under naturally ventilated polyhouse. Journal of Pharmacognosy and Phytochemistry 9(5):1117-1120. https://doi.org/10.22271/phyto.2020.v9.i5p.12378

Peña-Datoli M, Hidalgo C, González V, Alcántar E, Etchevers J (2016). Coating of corn (Zea mays L.) seeds with chitosan and sodium alginate and its effect on root development. Agrociencia 50(8):1091-1106. https://www.redalyc.org/articulo.oa?id=30249305011

Quilambaqui JMA (2005). Isolation and identification of Fusarium spp associated with the decline of asparagus (Asparagus officinalis L.) in five municipalities of Guanajuato, Mexico. Revista Tecnológica ESPOL 18(1):135140. https://doi.org/10.37815/rte

Reddy M, Arul J, Angers P, Couture L (1999). Chitosan treatment of wheat seeds induces resistance to Fusarium graminearum and improves seed quality. Journal of Agricultural and Food Chemistry 47(3):67-72. https://doi.org/10.1021/jf981225k

Renganathan P, Borboa-Flores J, Rosas-Burgos E, Cárdenas JL, Murillo-Amador B, Ortega-García J, Rueda-Puente EO (2018). Inoculation of nitrogen-fixing halobacteria in the contribution to tolerance to salt stress in bean tepary. Revista Mexicana de Ciencias Agrícolas 20:4289-4300. https://doi.org/10.18633/biotecnia.v21i1.875

Reyes Pérez J, Enríquez-Acosta E, Ramírez-Arrebato M, Zúñiga VE, Lara-Capistrán V, Hernández-Montiel, L (2020). Effect of chitosan on variables of tomato growth, yield and nutritional content. Revista Mexicana Ciencias Agrícolas 11(3):457-464. https://doi.org/10.29312/remexca.v11i3.2392

Djalali F, Katja W, Jan G, Rita G, Rita Z (2020). Species-specific impact of Fusarium infection on the root and shoot characteristics of Asparagus. Pathogens 9(6):509. https://doi.org/10.3390/pathogens9060509

Ruan S, Xue Q (2002). Effects of chitosan coating on seed germination and salt-tolerance of seedlings in hybrid rice (Oryza sativa L.) Acta Agronomica Sinica 28(6):803-808. https://europepmc.org/article/CBA/389657

SAGARPA (2017). Fecha de publicación. Querétaro Qro., lunes 30 de enero de 2017. http://www.sagarpa.gob.mx/Delegaciones/queretaro/boletines/Paginas/2017b011.aspx

Sas Institute (1996). SAS/STAT user's guide. Version 6.12 SAS, Institute, Cary, N.C. U.S.A.

Sato N, Murata N (1988). Membrane lipids. Methods in Enzimology 167:251-259. https://doi.org/10.1016/0076$6879(88) 67027-3$

Shao C, Hu J, Song W, Hu W (2005). Effects of seed priming with chitosan solutions of different acidity on seed germination and physiological characteristics of maize seedling. Journal of Zhejiang University. Agriculture and Life Science 31(6):705-708.

Shehata SA, Fawzy ZF, El-Ramady HR (2012). Response of cucumber plants to foliar application of chitosan and yeast under greenhouse conditions. Australian Journal of Basic and Applied Sciences 6(4):63-71. http://www.ajbasweb.com/old/ajbas/2012/April/63-71.pdf

Snedecor G (1956). Statistical methods applied to experiments in agriculture and biology. The Iowa State College Press, Ames, Iowa, USA, pp 237-290. 
Sokal R, James R (1988). Biometry: the principles and practice of statistics in biological research, 3nd edn. Freeman \& Co, San Francisco, CA. https://dialnet.unirioja.es/servlet/libro?codigo $=368526$

Tabassum B, Khan A, Tariq M, Ramzan M, Iqbal Khan MS, Shahid N, Aaliya K (2017). Bottlenecks in commercialization and future prospects of PGPR. Applied Soil Ecology 121:102-117. https://doi.org/10.1016/j.apsoil.2017.09.030

Tarrand JJ, Krieg NR, Dobereiner J (1978). A taxonomy study of the Spirillum lipoferum group, with descriptions of a new genus, Azospiriflum lipoferum (Beijerinck) comb. nov. and Azospirillum brasilense sp. nov. Canadian Journal of Microbiology 24:967-980. https://doi.org/10.1139/m78-160

Vargas TG, Taquez Bueno L (2018). Obtención y evaluación del Quitosano a nivel laboratorio para la depuración de aguas residuales industriales provenientes de un laboratorio cosmético. [Obtaining and evaluating Chitosan at the laboratory level for the treatment of industrial wastewater from a cosmetic laboratory]. Universidad Nacional Abierta y a Distancia - UNAD, Escuela de Ciencias Agrícolas, Pecuarias y del Medio Ambiente, Bogotá, Colombia. Tesis de ingeniería. https://repository.unad.edu.co/bitstream/10596/18323/1/53094495.pdf

Vera AK, Parismoreno RL (2017). Uso de quitosano en medios de cultivo para el desarrollo en la propagación in vitro de la Orquídea Cattleya spp. [Use of chitosan in culture media for the in vitro propagation of Orchid Cattleya spp. University of Guayaquil, Guayaquil Ecuador]. Universidad de Guayaquil, Guayaquil Ecuador. Tesis de ingeniería. http://repositorio.ug.edu.ec/bitstream/redug/12115/1/TESIS\%20JULIA\%20VALENCIA\%20PACHO.pdf

Waśkiewicza A, Irzykowskab L, Bocianowskic J, Karolewskib Z, Weberb Z, Piotr G (2013). Fusariotoxins in asparagus their biosynthesis and migration. Food Additives and Contaminants: Part A 30(7):1332-1338. https://doi.org/10.1080/19440049.2013.796095

Will ME, Sylvia DM (1990). Interaction of rhizosphere bacteria, fertilizer, and vesicular-arbuscular mycorrhizal fungi with sea oats. Applied and Environmental Microbiology 56(7):2073-2079. https://doi.org/10.1128/aem.56.7.2073-2079.1990

Xu Q, Guo SR, Li L, An YH, Shu S, Sun J (2016). Proteomics analysis of compatibility and incompatibility in grafted cucumber seedlings. Plant Physiology and Biochemistry 105:21-28. https://doi.org/10.1016/j.plaphy.2016.04.001

Zhou Y, Yang Y, Qi Zhang Z, Wang X, Hu X (2002). Effects of chitosan on some physiological activity in germinating seed of peanut. Peanut Science and Technology 31:22-25. http://en.cnki.com.cn/Article_en/CJFDTotalPEAN200201004.htm

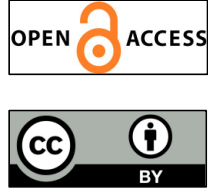

The journal offers free, immediate, and unrestricted access to peer-reviewed research and scholarly work. Users are allowed to read, download, copy, distribute, print, search, or link to the full texts of the articles, or use them for any other lawful purpose, without asking prior permission from the publisher or the author.

License - Articles published in Notulae Botanicae Horti Agrobotanici Cluj-Napoca are Open-Access, distributed under the terms and conditions of the Creative Commons Attribution (CC BY 4.0) License. (C) Articles by the authors; UASVM, Cluj-Napoca, Romania. The journal allows the author(s) to hold the copyright/to retain publishing rights without restriction. 